\title{
Performance of broiler chickens fed graded dietary levels of toasted jackfruit seed meal (Artocarpus heterophyllus)
}

Eburuaja, A. S., Onabanjo, R. S., *Onunkwo, D. N. and Ukenye, U. S. College of Animal Science and Animal Production, Michael Okpara University of Agriculture, Umudike, Umuahia, Abia State, Nigeria

*Corresponding author: donunkwo1@gmail.com; +2348033388622

\section{Abstract}

Effect of toasted jackfruit (Artocarpus heterophyllus) seed meal (TJSM) on performance of 1202 weeks old broiler chickens was investigated. The birds were divided into four dietary treatments having 3 replicates and 10 birds per replicate in a completely randomized design. Diet one $\left(T_{1}\right)$ was soybean based while toasted JFSM meal was added to diets $2\left(T_{2}\right), 3\left(T_{3}\right)$ and $4\left(T_{4}\right)$ at 5 , 10 and 15\% levels of inclusion, respectively. Growth performance was generally depressed with increased inclusion of toasted JFSM in the diets. Feed conversion ratio of birds fed $T_{1}$ and $T_{2}$ were the same and significantly better $(P>0.05)$ than those of the remaining treatment groups. Birds fed $T_{1}$ had significantly higher values of live weight, dressed weight and dressing percentage followed by birds fed $T_{2}$. The prime cut parts were similar in all the treatment groups. Organ proportions showed no significant differences across the treatment groups except the spleen. Cost per $\mathrm{kg}$ feed decreased with increased inclusion of TJSM. The cost of feed consumed was higher $(P>0.05)$ in $T_{1}(531.29)$ but decreased with increased inclusion of TJSM. The cost per kg weight gain, cost of production and revenue were similar across the treatment groups with birds fed $T_{1}$ significantly higher $(P>0.05)$ than the remaining treatment groups. The gross margin obtained for birds fed $T_{1}$ and $T_{2}$ are comparable and higher than other treatment groups. From the foregoing TJFSM is a potential feed resource and could be included in the diet of broiler chickens up to 5\% inclusion level.

Keywords: Utilization, Economics, Growth, Organ, Carcass

\section{Introduction}

Poultry has been identified as a means of bridging the protein intake deficiency in Nigeria.

The broiler chicken is a table bird or meat type bird. It is generally acceptable to majority of Nigerians. It is the quickest source of meat and its production is easily managed in relation to other livestocks enterprise (Obioha, 1992; Ojo, 2002; Taiwo, 2005. Under good management, broiler chickens attain live weight of about $2 \mathrm{~kg}$ on the average within 7 weeks. (Obioha, 1992). The main limitation to expansion of poultry industry is the availability of adequate supplies of needed feed ingredients at reasonable prices (Ani and Okorie, 2005; Babatunde and Hamzat, 2005). Feed account for about $70 \%$ of total cost of production (Ademola and Farinu, 2006). The high cost of feed is due mainly to competition between man and livestock for grains and conventional sources of plant (soybean, groundnut seed) and animal proteins (Adegbola, 1990; Emenalom, 2004). The most promising way to solve the problem of competition between man and animal for plant protein is to identify cheaper and easily available feed stuff that are of low human preference and little or no industrial use that can meet nutritional requirements of poultry with or without processing (Akinmutimi, A. H. 2001., Fanimo et al., 2004; Fasina et al., 2004). 


\section{Performance of broiler chickens fed graded dietary levels of toasted jackfruit seed}

One of such seeds that has potential of being used in poultry feed is Jackfruit seed meal (Artocarpus heteropophyllus). Jackfruit seed meal is lesser known in nutritional and agronomic researches. It was introduced to Nigeria from India and adapted so well in Nigeria, but not yet fully exploited as animal feed resource. The seeds are known to have nourishing qualities. The seed contains well flavored yellow sweet bulbs and seeds (embedded in the bulb). The edible bulbs are consumed fresh or processed into canned products. Seeds make-up around 10 to $15 \%$ of the total fruit weight and have high carbohydrate and protein contents (Bobbio et al., 1998 and Kumar et al., 1998). Akinmutimi et al. 2006 reported the proximate composition of Jackfruit seed to contains $89.88 \%$ dry matter, $27.57 \%$ crude protein, $3.06 \%$ ether extract $40.30 \%$ crude fiber, $4.0 \%$ ash, $50.99 \%$ nitrogen free extracts and $3.13 \mathrm{Kcal} / \mathrm{g}$ gross energy while Ndyomugyenyi et al. 2008 reported the following: dry matter of 92.5 , crude protein of 15.1 , ether extract of 0.983 , crude fiber of 4.20 , ash of 3.78 , nitrogen free extract of $74.0 \%$ and metabolizable energy of 13.3 $\mathrm{MJ} / \mathrm{g}$. Seeds are normally discarded or steamed and eaten as a snack or used in some local dishes. As fresh seeds cannot be kept for long time, seed flour can be an alternative product, which is used in some food products. There have been few studies on jackfruit seeds. Bobbio et al. (1978) reported some physicochemical properties, such as pasting characteristics of jackfruit seed starch. Kumar et al. (1988) studied the proximate compositions of two varieties of jackfruit seeds and reported considerable biochemical difference between the two varieties. The starch content of the seed increases with maturity (Rahman et al., 1999). Different locations give different seed contents. Jackfruit seed contains vitamin $\mathrm{A}$, vitamin $\mathrm{C}$, thiamin, riboflavin, calcium, potassium, iron, sodium, zinc, and niacin among many other nutrients. Jackfruit seed has a low caloric content: $100 \mathrm{~g}$ of jackfruit only contains 94 calories (Mukprasirt and Sajjaanantakul, 2004) anda rich source of potassium with $303 \mathrm{mg}$ found in $100 \mathrm{~g}$ of jackfruit. Studies show that food rich in potassium helps to lower blood pressure. Jackfruit seeds are a good source of starch $(22 \%)$ and dietary fiber (3.19\%) (Hettiarachchi et al., 2011). Jackfruit seed contains lignans, isoflavones, saponins, all phytonutrients and their health benefits are wide-ranging from anticancer to antihypertensive, antiaging, antioxidant, antiulcer, and also included in poultry ration (Omale and Friday 2010). Some anti-nutrients in Jackfruit seeds have been identified (Ndyomugyenyi et al., 2014b; Akinmutimi, 2006; Ravindran et al., 1996), but limited work has been done to quantify and eliminate them. Effective utilization of Jackfruit seed as feed for poultry would therefore depend on treatment methods that remove anti-nutrients from the seeds. Additionally, little research has been conducted to include the properly processed Jackfruit seed meal in poultry diets. Consequently, the optimum inclusion levels of different toasted Jackfruit seed meal in poultry diets have not yet been fully studied. Thus, this study was conducted to determine the safe level of inclusion of toasted jackfruit seed meal (TJSM) in the diet of broiler chicken.

\section{Materials and methods \\ Location of the experiment}

The experiment was carried out at the Poultry unit of the Research and Training Farm of the Michael Okpara University of Agriculture, Umudike, Abia State, Nigeria. Umudike is located on latitude $5^{0} 29^{1}$ North and longitude $7-0-32^{1}$ east in the rainforest zone of Nigeria. The climate of the region is characterized by a daily temperature range 


\section{Eburuaja, Onabanjo, Onunkwo and Ukenye}

of $27^{\circ} \mathrm{C}$ and $35^{\circ} \mathrm{C}$ throughout the year and an average rainfall of $200 \mathrm{~mm}$ per annum (NRCRI, 2004).

Procurement and processing of jackfruit seed

Jackfruit seeds were locally sourced in Michael Okpara University of Agriculture Umudike, College of Management Science and Anambra State in Nigeria. The seeds were removed from the fruits by hand, they were sun dried for 2 days and toasted for 15 minutes. The seeds after cooling were crushed into fine particle size and kept until needed.

\section{Chemical analysis}

Proximate composition and gross energy determination

The proximate composition of toasted JFSM was determined using the procedure described by the Association of Official
Analytical Chemists (A.O.A.C. 1990) while the gross energy was determined using Gallenkamp Ballistic bomb calorimeter.

\section{Experimental diets}

A total of four diets having crude protein of $23 \%$ and caloric densities of between 2906.70 to $2912.3 \mathrm{ME} / \mathrm{kg}$ were formulated as shown in Table 1 below. Maize was the major source of energy while soybean meal and JSM were the major sources of protein. TJSM was included in the four diets at the following levels $0,5,10$ and $15 \%$ in treatments $T_{1}, T_{2}, T_{3}$ and $T_{4}$, respectively. The diets were fortified with synthetic amino acids such as lysine and methionine. The feed was presented in mash form. Percentage composition of experimental diets is presented in Table 1 .

Table 1: Gross composition of experimental diets containing graded levels of toasted jackfruit seed meal (TJSM)

\begin{tabular}{|c|c|c|c|c|}
\hline \multirow[b]{2}{*}{ INGREDIENTS } & \multicolumn{3}{|c|}{ LEVELS OF INCLUSION OF TJSM } & \multirow[b]{2}{*}{$T_{3}(15 \%)$} \\
\hline & $T_{1}(0 \%)$ & $T_{2}(5 \%)$ & $T_{3}(10 \%)$ & \\
\hline Maize & 51 & 47 & 44 & 41 \\
\hline Soyabean meal & 33 & 31 & 29 & 27 \\
\hline TJSM & 0 & 5 & 10 & 15 \\
\hline Palm kernel cake & 10.50 & 10.50 & 10.50 & 10.50 \\
\hline Fish meal & 3.00 & 3.00 & 3.00 & 3.00 \\
\hline Bone meal & 3.00 & 3.00 & 3.00 & 3.00 \\
\hline Vitamin premix & 0.25 & 0.25 & 0.25 & 0.25 \\
\hline Salt & 0.25 & 0.25 & 0.25 & 0.25 \\
\hline Methionine & 0.10 & 0.10 & 0.10 & 0.10 \\
\hline Lysine & 0.20 & 0.20 & 0.20 & 0.20 \\
\hline Total & 100 & 100 & 100 & 100 \\
\hline \multicolumn{5}{|l|}{ Calculated composition } \\
\hline Crude protein $(\%)$ & 23 & 23 & 23 & 23 \\
\hline $\begin{array}{l}\text { Metabolizable energy } \\
(\mathrm{Kcal} / \mathrm{Kg})\end{array}$ & 2906.70 & 2909.54 & 2911.18 & 2912.73 \\
\hline $\begin{array}{l}\text { Each } 2.5 \mathrm{~kg} \text { of premix cont } \\
(1,600.00 \mathrm{mg}), \mathrm{b}_{2}(4000.0 \\
\mathrm{B}_{12}(10.000 .00 \mathrm{mg}) \text {, folic ac } \\
(3000.00 \mathrm{mg}), \text { lodine }(1000\end{array}$ & $00 \mathrm{mg}$ ), Bio & $00 \mathrm{mg}$ ), zi & $\begin{array}{l}(10,000.00 \\
00.00 \mathrm{mg}), \\
\mathrm{g}), \text { cobalt }(2 \\
\end{array}$ & $\begin{array}{l}\mathrm{k}_{3} \quad(1,50000 \mathrm{mg}), \mathrm{b}_{1} \\
\quad 6(1500.00 \mathrm{mg}), \mathrm{vit} \\
\text { 0mg), copper } \\
00) \text { Iron }(20,000 \mathrm{mg})\end{array}$ \\
\hline
\end{tabular}




\section{Experimental birds and management}

A total of 120, one-day old, Arbor acre strain of broiler chicks were procured from Chi farms Ibadan, Oyo State. The chicks were brooded together with a 60 watts bulb in a brooding pen in deeper litter house for the first seven days. Feed and water were supplied ad libitum to all the birds. They were fed commercial diet for one week to stabilize them. At 7 days old, 30 chicks were randomly allotted to each of the 4 dietary treatments. Each treatment was replicated 3 times with 10 birds per replicate. Feed and water were offered ad libitum to all the birds throughout the period of the experiment.

The chickens were given necessary vaccination and were also subjected to standard broiler management.

\section{Experimental design and statistical analysis}

The experimental design was completely randomized design. Data collected were subjected to analysis of variance (ANOVA) (Steel and Torrie, 1980). Means separation were carried out as described by Duncan's Multiple Range Test (Duncan, 1995).

\section{Results and discussion}

The proximate composition and gross energy of experimental diets containing graded levels of toasted JFM is presented in Table 2. The crude protein contents of the feed ranged from 17.50 to $23.00 \%$ and Metabolisable energy ranged from 3470.19 to $3577.03 \mathrm{kcal} / \mathrm{kg}$.

Table 2: Proximate composition and metabolizable energy of experimental diets containing graded levels of TJSM fed to broiler chickens

\begin{tabular}{lllll}
\hline \multirow{2}{*}{ Nutrients } & \multicolumn{4}{c}{ LEVELS OF INCLUSION OF TJSM } \\
\cline { 2 - 5 } & $\mathrm{T}_{1}(0 \%)$ & $\mathrm{T}_{2}(5 \%)$ & $\mathrm{T}_{3}(10 \%)$ & $\mathrm{T}_{4}(15 \%)$ \\
\hline Dry matter & 89.50 & 89.47 & 89.42 & 89.35 \\
Crude protein & 23.00 & 21.55 & 20.13 & 17.50 \\
Ether extract & 6.25 & 4.85 & 4.35 & 4.00 \\
Crude fibre & 6.65 & 7.25 & 11.18 & 13.27 \\
NFE & 45.65 & 48.22 & 46.57 & 47.78 \\
Metabolisable & 3577.03 & 3508.53 & 3495.58 & 3470.19 \\
energy (Kcal/kg) & & & & \\
\hline
\end{tabular}

The growth performance of broiler chicken fed different dietary levels of toasted jack fruit seed meal is presented in Table 3. With the exception of mean total feed intake, mean daily feed intake and initial weight of birds all other parameters examined under performance of broiler chicken fed graded levels of Toasted Jackfruit Seed Meal (TJSM) were significantly influenced $(p<0.05)$ by treatment diet. The mean final weight of birds, mean weight gain and mean daily weight gain followed a similar pattern. The values of these parameters decreased significantly $(p>0.05)$ as the quantity of TJFSM increased in the diets. Birds fed diet one had significantly high values of mean final weight (16633.33g) followed by diet 2
$(1333.33 \mathrm{~g})$ and treatments 3 and 4 has $1116.67 \mathrm{~g}$ and $1000.00 \mathrm{~g}$, respectively. Final body weight and total weight gain were significantly $(p<0.05)$ better in dietary group 1 than the other groups.

The most probable explanation for the observed depressed performance in birds fed diets 2, 3 and 4 was the inclusion of TJSM in the diets. The anti-nutritional factors in the toasted jackfruit seed meal might not have been removed completely with this processing method i.e toasting. Raw JSM contains anti-nutritional factors tannins, saponins, phytates and oxalate (Ndyomugyenyi et al., 2008; Eburuaja et al., 2017) which would have constituted a hindrance to bio availability of nutrients for 
Eburuaja, Onabanjo, Onunkwo and Ukenye

Table 3 : Growth performance of 8 -weeks old broiler chickens fed gr aded dietary levels of toasted jackfruit seed meal (TJSM)

\begin{tabular}{|c|c|c|c|c|c|}
\hline \multirow[b]{2}{*}{ Parameters } & \multicolumn{4}{|c|}{ LEVELS OF INCLUSION OF TJSM } & \multirow[b]{2}{*}{ SEM } \\
\hline & $T_{1}(0 \%)$ & $T_{2}(5 \%)$ & $\mathrm{T}_{3}(10 \%)$ & $T_{4}(15 \%)$ & \\
\hline Mean daily feed intake (g/bird/day) & 73.75 & 72.44 & 71.42 & 71.59 & 0.44 \\
\hline Mean total feed intake (g/bird) & 3097.33 & 3042.33 & 2999.67 & 3007.00 & 18.52 \\
\hline Initial body weight(g/bird) & 210.00 & 206.67 & 210.00 & 206.67 & 1.12 \\
\hline Final body wight(g/bird) & $1633.33^{\mathrm{a}}$ & $1333.33^{\mathrm{b}}$ & $1116.67^{\mathrm{bc}}$ & $1000.00^{c}$ & 79.88 \\
\hline Mean total weight gain(g/bird) & $1423.33^{\mathrm{a}}$ & $1126.67^{b}$ & $906.67^{\mathrm{bc}}$ & $793.33^{\mathrm{c}}$ & 79.47 \\
\hline Mean daily weight gain (g/bird/day) & $33.87^{\mathrm{a}}$ & $26.82^{b}$ & $21.59^{\mathrm{bc}}$ & $18.89^{\mathrm{c}}$ & 1.89 \\
\hline Feed to gain ratio & $2.18^{\mathrm{c}}$ & $2.70^{\mathrm{bc}}$ & $3.38^{\mathrm{ab}}$ & $3.95^{\mathrm{a}}$ & 0.25 \\
\hline Mortality & 0.00 & 0.00 & 0.00 & 0.00 & 0.00 \\
\hline
\end{tabular}

the birds. Tannin for example forms complex linkage with protein hence poor digestibility leading to loss of protein and hence poor growth (Akinmutimi, 2003). Phytic acid makes mineral unavailable for metabolic processes as it chelates them (Aletor and Fasuyi, 1997; Robberts et al., 2006) resulting in poor growth. Also, the rate of heat applied during toasting might have affected the bio-availability of nutrients such as crude protein to the broiler chicken. However, birds on diets 1 and 2 had the lowest feed to gain ratio which makes diet 1 comparable to diet 2 . It also indicates that the inclusion of TJFSM up to $5 \%$ in the diets of broiler chicken would yield the same desirable effect as those fed control diet. Table 4 shows the carcass yield of broiler chicken fed different dietary levels of toasted jackfruit seed meal. There was a significant difference in live weight across the groups as chickens fed control diet had highest mean followed by those fed diets 2, 3 and 4. This shows the better quality and nutritional composition of the control diet followed by diet 2 . Increase in the weight of birds is an indication of bioavailability of nutrients and quality of feed. The same trend was observed in the dressed weight. The dressing percentage showed that there was no significant difference $(p>0.05)$ between birds fed diets
2, 3 and 4 but they were significantly lower $(\mathrm{p}<0.05)$ than those fed control diet. This could also be due to quality and nutritional composition of the control diet. There were no significant differences in the drum stick, back cut, thigh and breast across the treatment groups. Birds fed diet 4 had significantly high value of wings $(15.30 \%)$ than birds fed control diet (13.54\%) but not significantly different from those fed diet 2 $(14.78 \%)$ and diet $3(14.82 \%)$. The nonsignificant difference $(\mathrm{p}>0.05)$ observed in the prime cut parts (breast, thighs, and drumsticks) across the treatment groups showed that with better processing methods, jackfruit seed meal could become better substitute for the expensive conventional feed stuff.

The effect of graded dietary levels of toasted jackfruit seed meal on organ weight of broiler chicken is shown in Table 5. There were no significant differences in the liver, gizzard and heart across the treatment groups. The spleen of birds fed diet 1 was significantly higher than those fed diet 2 but not significantly different from birds fed diets 3 and 4 . The non-significant difference observed in the values of liver, gizzard and heart of birds fed control diets and those fed toasted jackfruit seed meal indicates that the anti-nutritional factors in TJSM are at tolerable levels. 
Performance of broiler chickens fed graded dietary levels of toasted jackfruit seed

Table 4 : Effect of gr aded dietary levels of toasted jackfruit seed $m$ eal (TJSM) on carcass yield of broiler chickens

\begin{tabular}{|c|c|c|c|c|c|}
\hline \multirow[b]{2}{*}{ Parameters } & \multicolumn{4}{|c|}{ LEVELS OF INCLUSION OF TJSM } & \multirow[b]{2}{*}{ SEM } \\
\hline & $T_{1}(0 \%)$ & $T_{2}(5 \%)$ & $\mathrm{T}_{3}(10 \%)$ & $\mathrm{T}_{4}(15 \%)$ & \\
\hline Liveweight, g/bird & $1633.33^{\mathrm{a}}$ & $1333.33^{\mathrm{b}}$ & $1116.67^{\mathrm{bc}}$ & $1000.00^{c}$ & 79.88 \\
\hline Dressed weight, g/bird & $1116.67^{\mathrm{a}}$ & $800.00^{\mathrm{b}}$ & $683.33^{\mathrm{bc}}$ & $566.67^{\mathrm{c}}$ & 66.81 \\
\hline Dressing \% & $68.32^{\mathrm{a}}$ & $59.98^{\mathrm{b}}$ & $61.15^{\mathrm{b}}$ & $56.11^{\mathrm{b}}$ & 1.54 \\
\hline Drumstick \% & 1667 & 18.09 & 19. 34 & 17.66 & 0.57 \\
\hline Back cut $\%$ & 19.82 & 21.91 & 20.63 & 21.32 & 0.38 \\
\hline Back cut $\%$ & 19.82 & 21.91 & 20.63 & 21.32 & 0.38 \\
\hline Wings \% & $13.54^{\mathrm{b}}$ & $14.78^{\mathrm{ab}}$ & $14.82^{\mathrm{ab}}$ & $15.30^{\mathrm{a}}$ & 0.28 \\
\hline Thighs $\%$ & 18.52 & 19.18 & 18.06 & 18.65 & 0.20 \\
\hline
\end{tabular}

$\overline{a, b, c}$ means within the same row with different superscripts are significantly $(p<0,05)$ different. S. E M: standard error of mean.

Table 5: Effect of graded dietary levels of toasted jackfruit seed meal (TJSM) on organ weights of broiler chicken

\begin{tabular}{llllll}
\hline & \multicolumn{4}{c}{ LEVELS OF INCLUSION OF TJSM } & \\
\cline { 2 - 5 } Parameters & $\mathbf{T}_{\mathbf{1}}(\mathbf{0} \%)$ & $\mathbf{T}_{\mathbf{2}} \mathbf{( 5 \% )}$ & $\mathbf{T}_{\mathbf{3}}(\mathbf{1 0} \boldsymbol{)})$ & $\mathbf{T}_{\mathbf{4}}(\mathbf{1 5 \% )}$ & SEM \\
\hline Liver & 2.56 & 2.73 & 2.39 & 2.53 & 0.08 \\
Spleen & $0.26^{\mathrm{a}}$ & $0.14^{\mathrm{b}}$ & $0.15^{\mathrm{ab}}$ & $0.16^{\mathrm{ab}}$ & 0.02 \\
Gizzard & 2.59 & 2.78 & 2.75 & 2.93 & 0.08 \\
Heart & 0.54 & 0.59 & 0.50 & 0.56 & 0.02 \\
\hline
\end{tabular}

$\overline{a, b, c}$ means within the same row with different superscripts are significantly $(p<0,05)$ different. S. E M: standard error of mean.

Table 6 showed the economics of production of broiler chicken fed graded dietary levels of TJSM. Treatments 1 and 2 had statistically similar values of cost per kilogram feed which are significantly higher than those of treatments 3 and 4 . The reason could be because treatment 1 (control diet) is solely soybean and maize based and diet 2 contains small quantity of TJSM (5\%) while treatments 3 and 4 had more of TJSM. Maize and soybean must have accounted for the high values of cost per $\mathrm{Kg}$ feed in treatment 1 and 2. Maize and soybean are some of the costly conventional feed ingredients in poultry production because of competition between man and animals for them (Adegbola, 1990; Emenalom, 2004; Eburuaja et al., 2017). On the other hand, the low values of cost $/ \mathrm{kg}$ feed in treatment 3 and 4 may be due to the fact that the test ingredient (TJSM) incorporated in diets 3 and 4 was collected free of charge except for the cost of transportation.

Cost of feed consumed decreased as the quantity of TJSM increased with treatment 1 having the highest mean. This may also be because of the reduction in the quantity of costly soybean and maize as the quantity of TJSM increased. The cost per kg weight gained showed that control diet was significantly lower $(\mathrm{p}<0.05)$ than diet 4 while the remaining treatment groups were similar. Birds fed diet 4 had highest value of cost per kilogram weight gain probably because of bio-availability of nutrient which resulted into its having high feed conversion ratio (Table 4). The values of the cost of production showed that birds fed treatment 2, 3 and 4 were not significantly different $(p>0.05)$ from each other but were significantly lower than $(\mathrm{p}<0.05)$ the 


\section{Eburuaja, Onabanjo, Onunkwo and Ukenye}

control diet. Birds fed diet 1, 2 and 3 had significantly lower values of revenue than those under the control diet. The result of gross margin indicates that birds fed control diet and diet 2 are comparable and significantly higher than those of diet 4 . This suggests that inclusion of toasted jackfruit seed meal at $5 \%$ would produce the same result economically.

Table 6: Economics of production of broiler chicken fed graded dietary levels of toasted Jackfruit seed meal (TJSM)

\begin{tabular}{|c|c|c|c|c|c|}
\hline \multirow[b]{2}{*}{ Parameters } & \multicolumn{4}{|c|}{ LEVELS OF INCLUSION OF TJSM } & \multirow[b]{2}{*}{ SEM } \\
\hline & $T_{1}(0 \%)$ & $T_{2}(5 \%)$ & $T_{3}(10 \%)$ & $T_{4}(15 \%)$ & \\
\hline Cost $/ \mathrm{kg}$ feed & $171.53^{\mathrm{a}}$ & $163.87^{\mathrm{a}}$ & $156.21^{\mathrm{ab}}$ & $148.55^{\mathrm{b}}$ & 2.58 \\
\hline $\begin{array}{l}\text { Cost of feed } \\
\text { consumed }\end{array}$ & $531.29^{\mathrm{a}}$ & $498.55^{\mathrm{b}}$ & $468.58^{c}$ & $446.69^{d}$ & 9.88 \\
\hline $\begin{array}{l}\text { Cost } / \mathrm{kg} \text { weight } \\
\text { gain }\end{array}$ & $373.36^{\mathrm{b}}$ & $442.99^{\mathrm{ab}}$ & $527.47^{\mathrm{ab}}$ & $586.77^{\mathrm{a}}$ & 32.57 \\
\hline $\begin{array}{l}\text { Cost of } \\
\text { production }\end{array}$ & $529.78^{a}$ & $472.60^{\mathrm{b}}$ & $468.25^{\mathrm{b}}$ & $446.72^{\mathrm{b}}$ & 11.25 \\
\hline Revenue & $1423.33^{\mathrm{a}}$ & $1126.67^{\mathrm{b}}$ & $906.67^{\mathrm{bc}}$ & $793.33^{c}$ & 79.47 \\
\hline Gross margin & $893.29^{\mathrm{a}}$ & $654.06^{\mathrm{ab}}$ & $438.42^{\mathrm{bc}}$ & $346.62^{c}$ & 71.49 \\
\hline
\end{tabular}

\section{Conclusion and recommendation}

This study showed that inclusion of toasted jackfruit seed meal in diets of broiler chickens was beneficial in improving growth, higher carcass yield, better feed efficiency and enhanced economic value especially at $5 \%$ level of inclusion. It is recommended that toasted jackfruit seed meal could be used in broiler diet at 5\% since the level increased performance, reduced cost of production and had no deleterious effects on organ yield.

\section{References}

A.O.A.C. 1990. Association of Analytical Chemists. Official Methods of Analysis $5^{\text {th }}$ ed. Washington DC.

Adegbola, A. A. 1990. Proc. Workshop on rural poultry development in Africa IIe Ife. Pp. 19-23.

Ademola, S. G. and Farinu, G. O. 2006. Performance of laying birds fed diets containing forage meal of Tithonia diversifolia (Hems/A.
Gray) and antibiotics. Nig. J. of Animal Prod. 33(1): 58-68.

Akinmutimi, A. H. 2001. Effect of potashcooked lima bean (Phaseolus lunatus) on broiler starter diets. Niger Agric. 32, Pp. 109-118.

Akinmutimi, A. H. 2003. The effect of various processing method on proximate, gross energy and mineral composition of Mucuna utilis seed. Proc. of the Nigerian Soc. of Anim. Prod. Held at IAR and T Ibadan. Pp. 166-168.

Akinmutimi, A. H., Abasiekong, F. C. and Shoyinka, V. O. 2006. Raw sword bean meal as a substitute For soybean meal in broiler finisher diets. Journal of Animal and Vet. Advances 5(8):699-706.

Aletor, V. A. and Fasuyi, A. O. 1997. Nutrient composition and processing effects on cassava leaf (Manihot esculenta, cranzi) antinutrients. A paper presented at the 
2nd Annual Conference of Animal Science Association of Nigeria, Lagos. Pp. 231- 242.

Ani, A. O. and Okorie, A. U. 2005. The effect of graded levels of dehulled and cooked castor oil bean (Ricinus communis, L.) meal on performance of broiler starters. Nig. J. Anim. Prod. 35(1) 54-60.

Babatunde, B. B. and Hamzat, R. A. 2005. Effect of feeding graded levels of kolanut husk meal on the performance of cockerels. Nig. J. of Animal Prod.32(1):61-66.

Eburuaja, A.S., Onunkwo, D.N., Odukwe,C.N., and Onuachu, J.C. 2017. Performance of broiler chicken fed raw and jackfruit seed meal (Artocarpus heterophyllus). Nigerian J. of Anim. Prod. Vol. 44(2), 145-151.

Duncan, 1995. Mutiple Range and Mutiple Tests Biometrics 11:1-42.

Emenalom, O. O. 2004. "Comparative performance of broiler chicks fed diets containing differently processed Mucuna pruriens seed meals. Nig. J. Animal Prod. 2004. 31(1) 12-16.

Fanimo, A. O., Oduguwa, O. O., Adewu, T. E. and Lawal, A. I. 2004. Utilization of diet containing cashew-nut reject meal by winner pigs. Nig. J. of Anim. Prod. 31 (1) 22- 26

Fasina, O. E., Ologhobo, A. D., Aderinu, G. A., Ayoade, G. O., Adeyemi, A. O., Olayode, G. and Olubanjo, $O$. O. 2004. Toxicology assessment of Vernonia amygdaliana leaf meal in nutrition of starter broiler chicks. Nig. J.Anim. Prod.31 (1): 3-11
Ndyomugyenyi, E. K., Kyarisiima, C. C., Bareeba, F. B., Okot, M. W. 2008. Enaluation of the nutritional value of boiled Java plum beans in broiler chick diets. Livest. Res. Rural Dev., $20 \quad\left(\begin{array}{ll}1 & 2\end{array}\right)$. W w w . Irr.org/Irrd20/12/ndyo20212.htm.

NRCRI 2004. Agro-Metrologic unit. National Root and Crop Research Institute, Umudike,

Obioha, F. C. 1992. A guide to poultry production in the tropics $1^{\text {st }}$ edition Obioha, Acena public. Enugu, Nigeria. Pp18-35.

Ojo, S. O. 2002. Analysis of the risk factor in commercial poultry products in Osun State Nigeria. in V.A. Aletor and G.E. Onibi (eds). Increasing household protein consumption through improved livestock products. Proceeding of Nig. Society of Anim. Prod. 27: 342-344.

Robberts, K. M., Daryi, K. G., Peter, A. $M$ and Victor, W. R 2006. Happers Illustrated Biochemistry $27^{\text {th }}$ Edition. MC Graw-Hill, New York, USA.

Steel, R. G. D and Torrie, J. H. 1980. Principles and Procedures of Statistics. A biochemical approach ( $2^{\text {nd }}$ ed). McGraw-Hill book Co. New York, USA.

Taiwo, A. A., Adejujigbe, A. D., Adebowale, E. A., Oshotan, J. C. and David, O. O. 2005. Performance and nutrient digestibility of weaned rabbits fed forages supplemented with concentrate. Nig. J. Animal Prod. 32 (1) $74-78$

Received: $26^{\text {th }}$ August, 2019 Accepted: $19^{\text {th }}$ December, 2019 